\title{
Electrophysiological characteristics and radiofrequency ablation of right atrial flutter
}

\author{
Yoga Yuniadi, Muhammad Munawar, Otte J Rachman, Budhi Setianto, Dede Kusmana
}

\begin{abstract}
Abstrak
Tujuan penelitian ini untuk melihat karakteristik elektrofisiologi dan hasil ablasi frekuensi radio (AFR) pada flutter atrium (FLA) yang belum tersedia hingga saat ini di Indonesia. Tiga buah kateter elektroda multipolar dimasukkan perkutan ke dalam jantung lalu ditempatkan di sinus koronarius (SK), berkas His dan mengitari anulus trikuspid. Kateter ablasi 8 mm digunakan untuk AFR linier cavotrikuspid isthmus (CTI) pada FLA tipikal dan kebalikan tipikal. Blok bidireksional ditentukan atas dasar pemanjangan waktu konduksi dinding lateral bawah ke ostium SK dan sebaliknya lebih dari 90 mdet, dan/atau dengan cara pemacuan diferensial. Terdapat 27 subyek dengan 30 FLA terdokumentasi yang terdiri dari 19 tipikal, 5 tipikal terbalik dan 6 atipikal. Hanya 9 pasien yang tidak mempunyai penyakit jantung struktural. Rerata panjang siklus takikardia (PST) adalah 261,79 $\pm 42,84,226,5 \pm 41,23$, dan 195,4 $\pm 9,19$ mdet masing-masing untuk FLA tipikal, kebalikan tipikal dan atipikal $(p=0,016)$. Konduksi CTI menempati 60\% dari PST atau rerata 153,0 \pm 67,37 mdet. Aktivasi SK terbagi menjadi 3 jenis yaitu proksimal ke distal, distal ke proksimal dan fusi. AFR pada FLA tipikal dan tipikal terbalik sukses sebanyak $96 \%$ dengan tingkat kekambuhan 4,5\% pada rerata masa pengamatan $13 \pm 8$ bulan. Pada populasi penelitian ini jenis FLA terbanyak adalah FLA tipikal. Kebanyakan subyek menderita penyakit jantung struktural. AFR sangat efektif menyembuhkan FLA tipikal dan kebalikan tipikal. (Med J Indones 2007; 16:151-8)
\end{abstract}

\begin{abstract}
This study aimed to elaborate the electrophysiology characteristics and radiofrequency ablation (RFA) results of atrial flutter (AFL) which has not been established in Indonesia. Three multipolar catheters were inserted percutaneously and positioned into coronary sinus (CS), His bundle area and around tricuspid annulus. Eight mm ablation catheter was used to make linear ablation at CTI of typical and reverse typical AFL. Bidirectional block was confirmed by conduction time prolongation of more than 90 msec from low lateral to CS ostium and vice versa, and/or by means of differential pacing. Thirty AFL from 27 patients comprised of 19 typical AFL, 5 reverse typical AFL and 6 atypical AFL enrolled the study. Mean tachycardia cycle length (TCL) were 261.8 $\pm 42.84,226.5 \pm 41.23$, and $195.4 \pm 9.19 \mathrm{msec}$, respectively $(p=0.016)$. CTI conduction time occupied up to $60 \%$ of TCL with mean conduction time of 153.0 \pm 67.37 msec. CS activation distributed to three categories which comprised of proximal to distal, distal to proximal and fusion activation. Only nine of 27 patients had no structural heart disease. RFA of symptomatic typical and reverse typical AFL demonstrated $96 \%$ success and $4.5 \%$ recurrence rate during $13 \pm 8$ months follow up. Typical AFL is the predominant type of AFL in our population. The majority of AFL cases suffered from structural heart disease. RFA was highly effective to cure typical and reverse typical AFL. (Med J Indones 2007; 16:151-8)
\end{abstract}

Keywords: atrial flutter, electrophysiology, ablation

The atrial flutter (AFL) is a frequent arrhythmias second only to atrial fibrillation in clinical practice. Clinical consequences of untreated AFL includes of significant increase of thromboembolic events and tachycardiomyopathy result in marked decrease in quality of life. ${ }^{1}$

Department of Cardiology and Vascular Medicine, Faculty of Medicine, University of Indonesia/National Cardiovascular Center Harapan Kita, Jakarta, Indonesia
The clinical and electrophysiologic characteristics and radiofrequency ablation (RFA) results of atrial flutter (AFL) patients in Indonesia have not been established. Typical and reverse typical AFL together with other right AFL has been the major type of AFL all over the world, but there is no exact data on its prevalence in our country. The success rate of RFA of AFL has been reported very high, which was ranges between 90 to $100 \%$ depend on the type and location of reentry circuit. ${ }^{2,3}$ However, since the beginning of electrophysiology era in this country on early 1995 no report of success rate of AFL ablation. Therefore, this study 
aimed to have preliminary data of AFLs characteristics and its ablation results in National Cardiovascular Center Harapan Kita which is the only government's owned electrophysiology center in this country.

\section{METHODS}

\section{Study Population}

The data was revealed retrospectively from medical record and magnetic optical disc during period of April 2004 to October 2006. The study population included all AFL types. The diagnosis of AFLs was determined by electrophysiologist using standard ECG criteria. Typical AFL characterizes with "sawtooth" pattern in inferior leads. This usually consists of downsloping segment followed by sharper negative deflection then a sharp positive deflection with a positive "overshoot" leading to the next downsloping plateau. The relative size of each component can be variable. ${ }^{1}$ In contrast, during reverse typical AFL the flutter wave morphology show broad positive in inferior leads and wide negative in lead $V_{1}$. Other AFL who had not fulfilled those ECG criteria was diagnosed as atypical AFL. ${ }^{1}$ None of the patients had previously undergone diagnostic electrophysiological study. Written informed consent was obtained from all patient underwent electrophysiology study and/or RFA.

\section{Catheters Placement}

Three multipolar electrode catheters were position under monoplane fluoroscopic guidance. Two of them were inserted percutaneously via the right femoral vein. These comprised of a 7-F, deflectable quadripolar catheter (Livewire, Daig, Minnetonka, Minnesota) positioned at His bundle area and a 7-F, deflectable duo-decapolar catheter (Livewire, Daig, Minnetonka, Minnesota) placed around the tricuspid annulus with distal pole positioned at low lateral wall. Another 7-F, nondeflectable decapolar catheter which had central lumen (Daig, Minnetonka, Minnesota) was positioned at coronary sinus (CS) via right jugular vein. The position of catheter in CS lumen was confirmed by contrast injection via the central lumen of catheter. The proximal pole of CS catheter positioned at CS ostial. $^{4}$ A 7-F, $8 \mathrm{~mm}$ tipped quadripolar ablation catheter (Blazer, EPT, USA) positioned at cavotricuspid isthmus (CTI) (Figure 1)

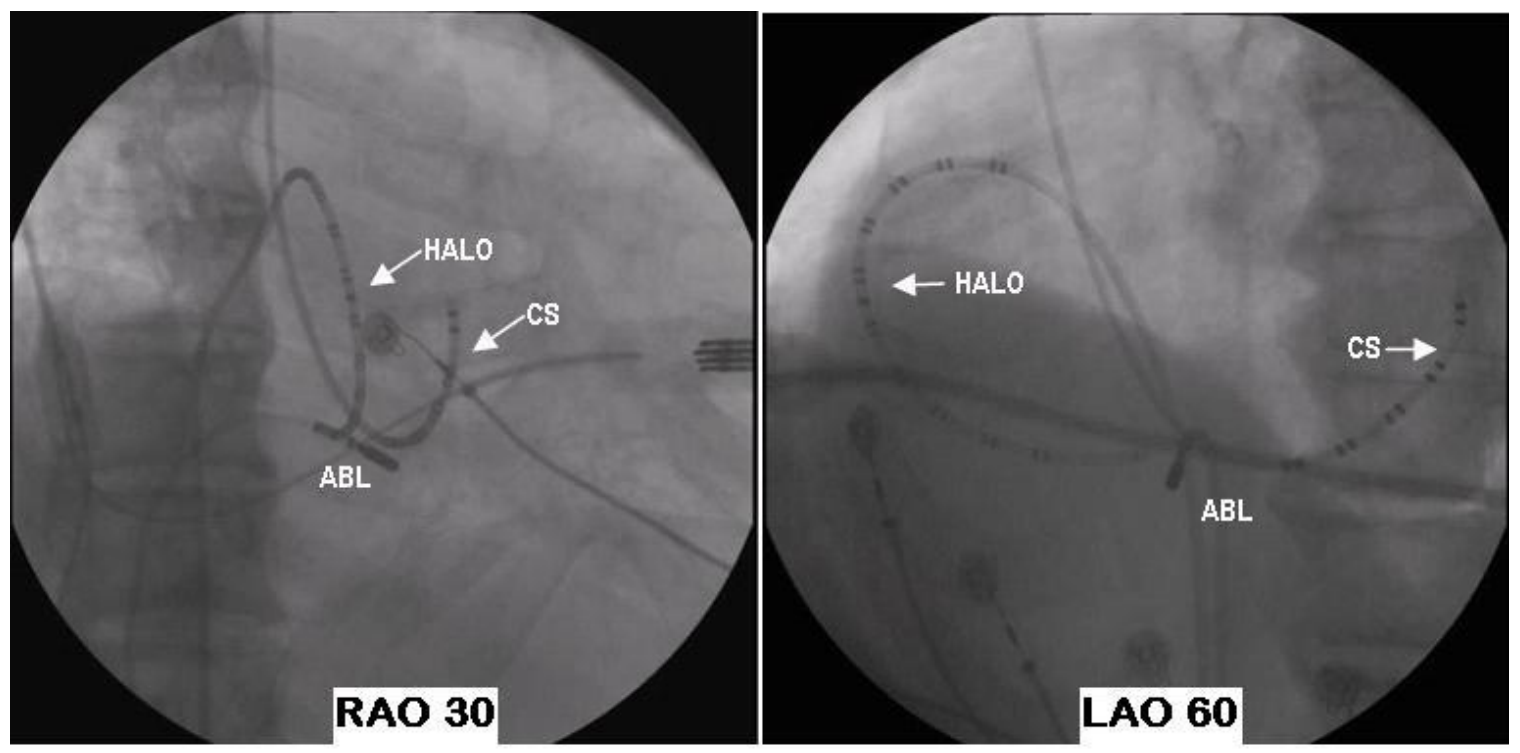

Figure 1. Fluoroscopy views of electrode and ablation catheters.

$H A L O=$ duodecapolar catheter placed around tricuspid annulus, CS = decapolar catheter placed inside coronary sinus with proximal pole at ostial, $A B L=$ ablation catheter placed at cavotricuspid isthmus, RAO $30=$ right anterior oblique 30 degree view, LAO 60 = left anterior oblique 60 degree view. 


\section{Electrophysiology Study Protocol}

Antiarrhythmia drugs were withheld at least five halflife before EP study. During sinus rhythm, conduction time from low lateral wall to CS ostial and vice versa were determined by pacing from distal pole of duodecapolar catheter and proximal pole of CS catheter respectively. It was done before and after radiofrequency ablation. AFL induction was performed by incremental and decremental pacing from lateral wall and/or CS. ${ }^{5}$ Incremental pacing was performed by giving 8 consecutive pacing with fixed coupling interval. Decremental pacing is incremental pacing with additional single pacing with decreasing coupling interval. Upon the FLA induction, the entrainment pacing of 10 to $30 \mathrm{~ms}$ less than flutter cycle length was performed at low lateral right atrium and/or CS ostium. Concealed entrainment and post pacing interval of $\leq 10 \mathrm{~ms}$ above the flutter cycle length considered that CTI is as part of reentry circuit during typical or reverse typical AFL. ${ }^{6}$

\section{Radiofrequency Ablation}

Linear RFA was performed with continuous temperature feedback control of power output to achieve a target temperature of $70^{\circ} \mathrm{C}$ for a maximum power of $70 \mathrm{~W}$ with 120 seconds duration. Ablation target was at the cavotricuspid isthmus (CTI) for typical and reverse typical AFL. ${ }^{7}$ Procedural success were defined by the evidence of bidirectional CTI block following RFA as confirmed by low lateral to CS ostial conduction time prolongation of more than 90 second and vice versa ${ }^{8}$ and/or positive result of differential pacing. ${ }^{9}$ No specific RFA for atypical AFL since our mapping tool was limited but atrioventricular junction (AVJ) ablation and pacemaker implantation was performed as indicated.

\section{Statistical Analysis}

Continuous data presented as mean $\pm \mathrm{SD}$. The differences of tachycardia cycle length (TCL) and CTI conduction between AFL types were analyzed using non-parametric statistic since the number of cases was limited. Chi square or Fisher Excact and KruskalWallis test was used to analyze the different between groups. A p value of $<0.05$ was considered statistically significant.

\section{RESULTS}

\section{Clinical Characteristics}

During the study period, 242 consecutive patients underwent electrophysiology study and/or RFA. The study population included 27 patients $(51.6 \pm 15$ yo) with 30 documented AFLs comprised of 19 typical AFL, 5 reverse typical AFL and 6 atypical AFL. One patient had both typical and reverse typical AFL, and another patient had both typical and atypical AFL. The subjects consist of 16 male and 11 female with the mean age of $54 \pm 13$ and $48 \pm 18$ years old respectively. Thirteen patients had incessant tachycardia and intermittent in the remainder.

Only 9 of 27 patients had no documented structural heart disease. In the remainders structural heart diseases comprised of 6 coronary artery disease, 1 aortic dissection, 3 valvular heart disease, 1 dilated cardiomyopathy, 1 post surgery of congenital heart disease, 6 hypertensive heart disease and 3 in conjunction with atrioventricular nodal reentry tachycardia. The mean ejection fraction was $45 \pm 16 \%$. Five patients had severe left ventricle dysfunction with ejection fraction $<35 \%$ and one of them experienced of acute lung edema during EP study. Four patients had left atrial enlargement and 3 patients had left ventricular hypertrophied.

\section{Electrophysiology study and RFA outcome}

In all patients without incessant tachycardia, AFLs were induced by right atrial or coronary sinus decremental pacing. There were no statistical different between incessant and inducible group in terms of TCL $(248.5 \pm 41.51 \mathrm{msec}$ and $231.8 \pm 54.75 \mathrm{msec}$, respectively, $\mathrm{p}=0.404)$; of their age $(53 \pm 16$ yo vs. $51 \pm 15$ yo, respectively, $p=0.534)$; and neither of the CTI conduction time $(165.9 \pm 67.26 \mathrm{msec}$ vs. $95.0 \pm$ $31.11 \mathrm{msec}$, respectively, $\mathrm{p}=0.156$ ).

During typical AFL, activation sequence demonstrated counterclockwise direction as it was traveled from Halo 19,20 (septum) to Halo 1,2 (low lateral). The wavefront ascended along the septum to the roof and traveled down to the low lateral wall across the CTI and exited at the septum to complete the flutter circuit. The mean TCL was $261.8 \pm 42.84$ msec. Conduction along the CTI was slow and occupied of mean $162.4 \pm 71.49 \mathrm{msec}(60 \%$ of flutter cycle length). (Table 1 and Figure 2) During reverse typical AFL, the activation sequence was clockwise direction 
as it was traveled from low lateral up to the roof then down to the septum and across the CTI back to the low lateral wall to complete the flutter circuit. The mean TCL of reverse typical AFL was $226.5 \pm 41.23 \mathrm{msec}$ which was not different with that of typical AFL $(p=0.222)$. Meanwhile, the atypical AFL demonstrated much shorter TCL $(195.4 \pm 27.31 \mathrm{msec})$ and the CTI conduction was $110.5 \pm 9.19 \mathrm{msec}$. The KruskalWallis test revealed that TCL between those three groups AFL was significantly different $(p=0.016)$

Coronary sinus activations, which were available in 15 AFLs, comprised of 8 proximal to distal (PD), 4 distal to proximal (DP) and 3 fusion activations. Among typical AFL, 6 (67\%) patients had PD, 2 (22\%) patients had DP activation, and $1(11 \%)$ patient had fusion activation. During reverse typical AFL 2 (75\%) had fusion activation. Two (33\%) patients with atypical AFL had PD and another 2 (33\%) had DP activation.

Of 6 atypical AFL patients, only 2 patients in conjunction with typical AFL had atrioventricular junction ablation, but the remainders had no ablation. One patient with severe left ventricle dysfunction suffered from acute lung edema during procedure, and another had nonsustained polymorphic ventricular tachycardia.

One typical AFL patient, who had a deep pouch in CTI, failed to reach bidirectional block eventhough the power increased up to 100 Joule. The others had a successful CTI ablation without any complication. (Figure 3) Bidirectional block was established with prolongation of conduction time from CS ostium to low lateral $(122 \pm 38 \mathrm{msec})$ and vice versa $(120 \pm 39$ msec). One case did not achieved CTI conduction prolongation of more than $90 \mathrm{msec}$ and the bidirectional block was confirmed with differential pacing technique. During median follow up of 13 months, 2 patients had recurrent of typical AFL. The one that bidirectional block confirmed by differential pacing underwent successful second procedure. Another case who failed to reach bidirectional block finally underwent $\mathrm{AV}$ junction ablation and pacemaker implantation since the AFL was very symptomatic.

Table 1. Clinical and Electrophysiological Characteristics

\begin{tabular}{lcccc}
\hline \multicolumn{1}{c}{ Variables } & Typical & Rev. Typical & Atypical & All \\
\hline Gender & 12 & 3 & 3 & 18 \\
• Male & 7 & 2 & 3 & 12 \\
• Female & $53.6 \pm 15.70$ & $43.4 \pm 12.40$ & $55.7 \pm 14.69$ & $52.2 \pm 15.09$ \\
\hline Age (year) & $46.4 \pm 16.03$ & $41.0 \pm 20.22$ & NA & $45.1 \pm 16.35$ \\
\hline Ejection Fraction (\%) & & & & \\
\hline Structural Heart Diseases & 4 & 0 & 2 & 6 \\
• HHD & 2 & 0 & 2 & 6 \\
• CAD & 1 & 0 & 0 & 3 \\
- VHD & 0 & 1 & 0 & 1 \\
• Cardiomyopathy & 3 & 1 & 1 & 5 \\
• Others & $261.8 \pm 42.83$ & $226.5 \pm 41.23$ & $195.4 \pm 27.31$ & $241.2 \pm 47.30$ \\
\hline TCL (msec) & $162.4 \pm 71.49$ & NA & $110.5 \pm 9.19$ & $153.0 \pm 67.37$ \\
\hline CTI conduction (msec) & & & & \\
\hline CS Activation & 6 & NA & 2 & 8 \\
• PD & 2 & NA & 2 & 4 \\
$\bullet$ DP & 1 & 2 & NA & 3 \\
\hline - Fusion & & & & \\
\hline
\end{tabular}

$\mathrm{HHD}=$ hypertensive heart disease, $\mathrm{CAD}=$ coronary artery disease, $\mathrm{VHD}=$ valvular heart disease, TCL = tachycardia cycle length, $\mathrm{CTI}=$ cavotricuspid isthmus, $\mathrm{PD}=$ proximal to distal, $\mathrm{DP}=$ distal to proximal, $\mathrm{NA}=$ not available 



Figure 2. Intracardiac electrogram of typical atrial flutter

Left panel is the schema shows HALO catheter (Duodecapolar) placement around tricuspid annulus. This catheter records the activation sequence during typical atrial flutter which has counterclockwise direction (right panel). Note the activation at HALO proximal (HALO 19,20) is earlier than distal (HALO 1,2). The coronary sinus activation demonstrates proximal $(C S 9,10)$ to distal activation sequence (CS 1,2). The cavotricuspid isthmus activation (CTI), which was measured from CS 9,10 to HALO 1,2, was slow as it was occupied about $60 \%$ of flutter cycle length (FCL).

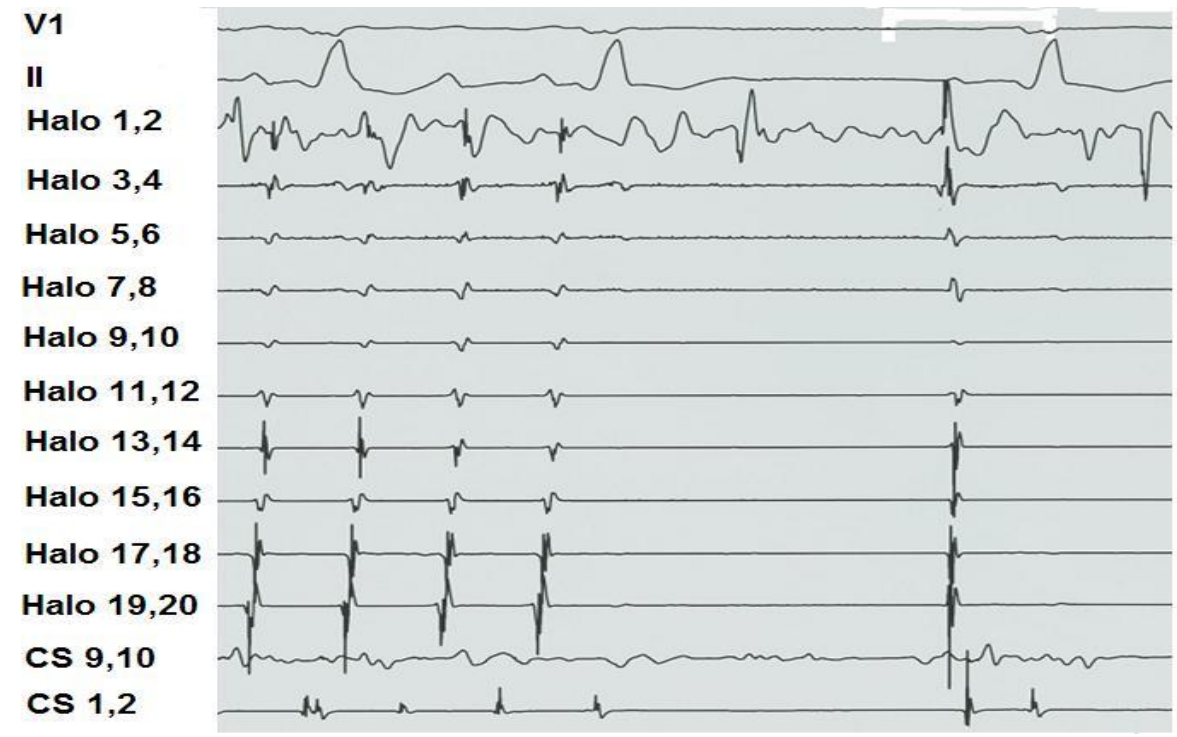

Figure 3. From atrial flutter to sinus rhythm

This figure demonstrates termination of atrial flutter and changes to sinus rhythm during radiofrequency ablation of cavotricuspid isthmus. 


\section{DISCUSSION}

\section{Main Finding}

This study showed that there were significant proportions of AFL cases (11\%) among them performed electrophysiology study and/or radiofrequency ablation. Typical AFL is the most frequent type of AFL. The majority of cases had structural heart disease. Electrophysiological characteristic of AFL in our population was similar to others studies. Radiofrequency ablation was effective to cure of typical and reverse typical AFL.

\section{Macroreentry circuit during AFL}

The mechanism of AFL is macroreentrant where the reentrant activation circulating around a large central obstacle, generally several centimeters in diameter. The central obstacle may consist of normal or abnormal structures. The obstacle can be fixed, functional or combination of the two. There is no single point of origin of activation, and atrial tissues outside the circuit are activated from various parts of the circuit. Description of macroreentrant mechanism has to be made in relation to right or left atrial anatomy, including a careful description of the obstacles and critical isthmuses that may be targets for therapeutic action. ${ }^{1}$

The average tachycardia cycle length during typical and reverse typical AFL in our study were $261.8 \pm$ $42.83 \mathrm{msec}$ and $226.5 \pm 41.23 \mathrm{msec}$ respectively, which is comparable with others studies. Previous studies found that the usual cycle length of macroreentrant tachycardia ranges between 190 and $250 \mathrm{msec}$, with $\leq 2 \%$ cycle to cycle variation. ${ }^{1,7}$ Interestingly, statistical analysis of TCL among 3 AFL groups (typical, reverse typical and atypical) were significantly different $(\mathrm{p}=$ 0.016). Since the TCL of typical was not different with that of reverse typical AFL, thus the difference between the 3 groups AFL was caused by marked reduce of TCL during atypical AFL. Atypical AFL has been reported to have shorter TCL as compared to typical AFL. ${ }^{3}$

We found that CTI conduction was slow and occupied up to $60 \%$ flutter cycle length during typical. Several studies consistently showed that CTI, which is defined as a path bounded by orifice of inferior vena cava, Eustachian valve/ridge, coronary sinus ostium and tricuspid annulus, is a zone of slow conduction during AFL. ${ }^{10,11}$ It has been proven that CTI owns decremental conduction properties or rate dependent conduction delay which is not found in the right atrial free wall. ${ }^{11}$ The mechanism of slow conduction in CTI was assumed to be due to nonuniform anisotropic conduction. It was Spach et al the first to show that aging or atrial dilatation leading to intercellular fibrosis changing that can change the density of gap junctions and produce nonuniform anisotropic. ${ }^{12}$

Kalman et al showed that all sites around the circumference of the tricuspid annulus were a part of the flutter reentrant circuit during typical AFL as it was confirmed by equal post pacing interval compare to that during tachycardia. ${ }^{6}$ Thus, the tricuspid annulus is the anterior fixed barrier in typical AFL. Furthermore, using intracardiac echocardiography to place multipolar catheter along the length of the crista terminalis and eustachian ridge, Olgin et $\mathrm{al}^{13}$ recorded split potentials along these structures which disparate activation of each component. Using entrainment technique, they showed that one component of the split potential is within reentrant circuit while the other is not. These findings are the strong evidence that the structures forming the posterior barrier in typical AFL. However, Friedman et al found that a functional line of block was present at the posteromedial (sinus venosa region) right atrium during typical and reverse typical AFL, suggesting that crista terminalis block was not always required for the maintenance of typical AFL. ${ }^{14}$ In addition, in series of 47 cases of typical and atypical AFL, I found that in $8 \%$ cases the activation wavefront cross the narrow conduction gap in the crista terminalis as it was demonstrated by noncontact mapping system. ${ }^{15}$

\section{Entrainment}

All typical AFL patients were able to be entrained and showed concealed entrainment. Waldo et al was the first to show that AFL could be entrained up to faster rates by rapid atrial pacing. When AFL is so entrained, termination of pacing is not followed by interruption of the AFL because a critical rate of pacing has not been reached. In order to interrupt atrial flutter successfully with rapid atrial pacing, the atria must be paced at a rate which is too fast for the flutter rhythm to follow. ${ }^{16}$ During entrainment pacing from area close to CS ostial, they observed the flutter wave polarity changed from negative to positive in lead II. Later, Tai et al demonstrated that sufficient incremental pacing from low lateral right atrium produced gradual conduction delays and block in isthmus of counterclockwise wavefront and initiated 
clockwise AFL. In the other hand, incremental pacing from coronary sinus ostium produced gradual conduction delays and block in the isthmus of clockwise wavefront and initiated counterclockwise AFL. ${ }^{11}$

Concealed entrainment which is defined as orthodromic pacing penetration without change of the ECG morphology and activation sequence and the AFL resume upon the pacing termination. ${ }^{17}$ Concealed entrainment was shown during pacing from low lateral right atrium and CS ostium in typical and reverse typical AFL suggesting that CTI is a part of reentry circuit. Finally it was proven by successful AFL termination after CTI linear ablation.

\section{CS Activation}

Coronary sinus activation pattern in our series of typical and reverse typical AFL could be divided into 3 categories. The majority of typical AFL had PD CS activation, in contrast to reverse typical AFL who had most fusion CS activation. Marine et al observed similar results of CS activation but their data showed more distributed pattern. They assumed that left atrial activation during typical and reverse typical AFL predominantly over CS ostium and Bachmann's bundle respectively. The statistical analysis showed significant proportion of CS activation between AFL groups ( $\mathrm{p}=$ $0.037)$.

\section{Radiofrequency Ablation}

We used $8 \mathrm{~mm}$ ablation catheter in order to make line of ablation in the CTI for typical and reverse typical AFL. Using particular technique we achieved 96\% success rate to produce bidirectional block in CTI. Tsai et al compared the efficacy and safety of $8 \mathrm{~mm}$ and $4 \mathrm{~mm}$ ablation catheter in order to make bidirectional block in CTI of typical AFL patient. They found that $8 \mathrm{~mm}$ ablation catheter has better efficacy and safe. ${ }^{18}$

The CTI has been established as a target of radiofrequency ablation of typical and reverse typical AFL. The end point of CTI ablation is the achievement of bidirectional block. There were many techniques to confirm bidirectional block in CTI. ${ }^{9,19-21}$ This study was used low lateral to CS ostium conduction time prolongation of more than $90 \mathrm{msec}$ and vice versa as the sign of bidirectional block. Tada et $\mathrm{al}^{8}$ studied 30 series of typical AFL patients and found that if an interval separating two components of double potentials less than 90 msec was always associated with local gap, whereas the interval of same or more than $110 \mathrm{msec}$ was always associated with local block. When the interval was between 90 and $110 \mathrm{msec}$, an isoelectric segment within double potentials and the negative polarity in the second component of double potentials were helpful in indicating local isthmus block. One patient did not achieved the desired conduction time prolongation but showed positive differential pacing result. Shah et al was showed that in the existence of bidirectional block, pacing from distal pole of duodecapolar catheter owned longer conduction time to CS ostium as compare to that during pacing from more proximal pole. This technique has been introduced as differential pacing by the authors. ${ }^{9}$

In one patient who failed ablation, pouch at the CTI was identified during contrast angiogram. Using intracardiac echocardiography, Morton et al has demonstrated the variable structures of CTI including the recess, pouch and variable degree of thickness. Intracardiac echocardiography is able to guide to avoid RFA in unfavorable structures in $\mathrm{CTI}^{27}$ The existence of pouch and much thickness structure of CTI, as confirmed by very high energy requirement (up to 100 watt), was assumed to be the cause of failed ablation.

During long term follow up, only one whose previous bidirectional block determined by differential pacing criteria, experienced recurrent typical AFL and had successful second procedure. Even though, RFA of typical and reverse typical AFL highly effective, there is still low frequency of recurrent rate. Tai et $\mathrm{al}^{2}$ studied 144 typical AFL patients and found that $6 \%$ of patients who achieved bidirectional block, experienced recurrent AFL over $17 \pm 13$ months follow up. Uniand multivariate analysis did not reveal any recurrent predictor.

\section{Limitations}

Limited number of atypical AFL in this study might not describe its actual clinical and electrophysiological characteristics; however the real prevalence of atypical AFL itself is small.

\section{CONCLUSION}

Typical AFL is the predominant type of AFL in our population. The majority of AFL cases demonstrated co-morbidity with structural heart disease. Linier RFA of CTI highly effective to cure typical and reverse typical AFL. 


\section{Acknowledgement}

Authors acknowledge Dr. Erika Maharani for her great assistance in collecting the data of the study.

\section{REFERENCES}

1. Saoudi N, Cosio F, Waldo A, Chen SA, Iesaka Y, Lesh $\mathrm{M}$, et al. A classification of atrial flutter and regular atrial tachycardia according to electrophysiological mechanisms and anatomical bases; a Statement from a Joint Expert Group from The Working Group of Arrhythmias of the European Society of Cardiology and the North American Society of Pacing and Electrophysiology. Eur Heart J. 2001;22:1162-82.

2. Tai CT, Chen SA, Chiang CE, Lee SH, Wen ZC, Huang JL, et al. Long-term outcome of radiofrequency catheter ablation for typical atrial flutter: risk prediction of recurrent arrhythmias. J Cardiovasc Electrophysiol. 1998;9:115-21.

3. Yang Y, Cheng J, Bochoeyer A, Hamdan MH, Kowal RC, Page R, et al. Atypical right atrial flutter patterns. Circulation. 2001;103:3092-8.

4. Tai CT. What is the best approach to ablation of typical atrial flutter? Heart Rhythm. 2004;1:49-50.

5. Lin JL, Lai LP, Lin LJ, Tseng YZ, Lien WP, Huang SK. Electrophysiological determinant for induction of isthmus dependent counterclockwise and clockwise atrial flutter in humans. Heart. 1999;81:73-81.

6. Kalman JM, Olgin JE, Saxon LA, Fisher WG, Lee RJ, Lesh MD. Activation and entrainment mapping defines the tricuspid annulus as the anterior barrier in typical atrial flutter. Circulation. 1996;94:398-406.

7. Shah DC, Haissaguerre M, Jais P, Takahashi A, Clementy J. Atrial flutter: contemporary electrophysiology and catheter ablation. Pacing Clin Electrophysiol. 1999;22:344-59.

8. Tada H, Oral H, Sticherling C, Chough SP, Baker RL, Wasmer K, et al. Double potentials along the ablation line as a guide to radiofrequency ablation of typical atrial flutter. J Am Coll Cardiol. 2001;38:750-5.

9. Shah D, Haissaguerre M, Takahashi A, Jais P, Hocini M, Clementy J. Differential pacing for distinguishing block from persistent conduction through an ablation line. Circulation. 2000;102:1517-22.

10. Feld GK, Mollerus M, Birgersdotter-Green U, Fujimura O, Bahnson TD, Boyce $\mathrm{K}$, et al. Conduction velocity in the tricuspid valve-inferior vena cava isthmus is slower in patients with type I atrial flutter compared to those without a history of atrial flutter. J Cardiovasc Electrophysiol. 1997; $8: 1338-48$
11. Tai CT, Chen SA, Chiang CE, Lee SH, Ueng KC, Wen $\mathrm{ZC}$, et al. Characterization of low right atrial isthmus as the slow conduction zone and pharmacological target in typical atrial flutter. Circulation. 1997;96:2601-11.

12. Spach MS, Dolber PC. Relating extracellular potentials and their derivatives to anisotropic propagation at a microscopic level in human cardiac muscle. Evidence for electrical uncoupling of side-to-side fiber connections with increasing age. Circ Res. 1986;58:356-71.

13. Olgin JE, Kalman JM, Fitzpatrick AP, Lesh MD. Role of right atrial endocardial structures as barriers to conduction during human type I atrial flutter. Activation and entrainment mapping guided by intracardiac echocardiography. Circulation. 1995;92:1839-48.

14. Friedman PA, Luria D, Fenton AM, Munger TM, Jahangir A, Shen WK, et al. Global right atrial mapping of human flutter: the presence of posteromedial (sinus venosa region) functional block and double potentials: a study in biplane fluoroscopy and intracardiac echocardiography. Circulation. 2000;101:1568-77.

15. Yuniadi Y, Tai CT, Huang BH, Higa S, Liu TY, Lin YJ, et al. Non-contact mapping of right atrial activation during typical atrial flutter with variable ECG morphology. Circulation. 2003;108:IV-542.

16. Waldo AL, MacLean WA, Karp RB, Kouchoukos NT, James TN. Entrainment and interruption of atrial flutter with atrial pacing: studies in man following open heart surgery. Circulation. 1977;56:737-45.

17. Cosio FG, Lopez GM, Arribas F, Palacios J, Goicolea A, Nunez A. Mechanisms of entrainment of human common flutter studied with multiple endocardial recordings. Circulation. 1994;89:2117-25.

18. Tsai CF, Tai CT, Yu WC, Chen YJ, Hsieh MH, Chiang $\mathrm{CE}$, et al. Is 8-mm more effective than 4-mm tip electrode catheter for ablation of typical atrial flutter? Circulation. 1999;100:768-71.

19. Tai CT, Haque A, Lin YK, Tsao HM, Ding YA, Chang MS, et al. Double potential interval and transisthmus conduction time for prediction of cavotricuspid isthmus block after ablation of typical atrial flutter. J Interv Card Electrophysiol. 2002;7:77-82.

20. Chen SA, Chiang CE, Wu TJ, Tai CT, Lee SH, Cheng $\mathrm{CC}$, et al. Radiofrequency catheter ablation of common atrial flutter: comparison of electrophysiologically guided focal ablation technique and linear ablation technique. J Am Coll Cardiol. 1996;27:860-8.

21. Tsai CF, Chen SA, Tai CT, Chiang CE, Yu WC, Chen YJ, et al. Impact of transisthmus linear ablation of typical atrial flutter on coronary sinus activation time. Pacing Clin Electrophysiol. 2000;23:63-73. 